\title{
Shore topography and spatial partitioning of crevice refuges by sessile epibenthos in an ice disturbed environment*
}

\author{
Pierre Bergeron \& Edwin Bourget \\ GIROQ, Département de biologie, Université Laval, Ste-Foy, Québec GlK 7P4, Canada
}

\begin{abstract}
The effect of substratum heterogeneity on the distribution and abundance of sessile epibenthos was studied between May 1980 and September 1981, in a mid-intertidal shore subject to severe annual ice scouring during winter In summer, low abundances of organisms were associated with smooth regular surfaces whereas high abundances were associated with higher heterogeneity in the form of cracks and crevices in the substratum. The barnacle Semibalanus balanoides, the seaweed Fucus vesiculosus and the mussel Mytilus edulis co-occured in crevice microhabitats. Effect of physical factors (crevice shape and size, exposure to ice erosion) on space partitioning within crevices was examined. The above species occured in distinct zones along the vertical gradient of crevice walls. $M$. edulis occupied the bottom of the crevices, while $S$. balanoides and $F$. vesiculosus colonized the intermediate zone immediately above mussels. The upper limit of all species varied with crevice width (angle formed by the sides) and depth. Upper limit of barnacles is determined by differential juvenile mortality during winter while their lower limit is determined by preemptive and probably interference competition for space with mussels. The near absence of barnacles outside crevices is due to lack of settlement there. The only true refuge for $S$. balanoides is in a narrow zone along the crevice walls. The importance of spatial and temporal variations in settlement as well as varying susceptibilities of different species to disturbances are discussed in relation to space partitioning. The relative importance of spatial heterogeneity on community structure in subarctic, temperate and tropical intertidal environments is compared.
\end{abstract}

\section{INTRODUCTION}

In Arctic, subarctic, and boreal regions where formation of shore ice occurs, there is a probability that attached intertidal organisms will be dislodged by ice scouring. Such events can occur annually or only occasionally depending on the rigor of the climate and/or conditions during ice-breakup. In these northern regions, the damaging effects of ice abrasion on shore populations are often overwhelming and therefore it is not surprising that ice has been de facto recognized as a predominant factor responsible for the relative barrenness of the shore. As a consequence the body of literature dealing with the qualitative effects of ice is much more important than that evaluating the quantitative effects (Bergeron \& Bourget 1984).

\footnotetext{
- Contribution to the program of GIROQ (Groupe Interuniversitaire de Recherches Océanographiques du Québec)
}

Most quantitative studies in the intertidal zone deal with the frequency of scouring on species diversity and successional changes. Where the frequency of scouring is annual or near-annual, species diversity is low (Hooper 1981, O'Clair 1981, South 1983) and this repeated disturbance appears to arrest succession at an early stage (Hooper 1981, O'Clair 1981, Archambault \& Bourget 1983, Bolton 1983, Bourget et al. 1985). When the frequency of scouring is lower, severe mortality can nevertheless occur and therefore modify community structure (Wethey 1979, Mathieson et al. 1982).

On the rocky platforms of the gulf of St. Lawrence, where ice perturbations occur annually, preliminary observations showed that dominant perennial species were found almost exclusively in cracks, crevices and at the base of boulders. Similar observations have been reported for various ice-abraded shores (see Bergeron \& Bourget 1984) suggesting that the degree of substratum heterogeneity, the variation in surface contour, is a major factor determining the abundance of interti- 
dal species. On shores abraded annually by ice, cracks and crevices represent the only possible refuge against perturbations. Thus it is probable that variations in the shape of these microhabitats will influence population dynamics and species interactions.

This study analyses how abiotic perturbations and habitat heterogeneity influence biological patterns and species persistence in a northern mid-intertidal zone strongly affected by winter conditions, particularly ice abrasion. We examine (1) the distribution and abundance of 3 dominant species, the barnacle Semibalanus balanoides, the mussel Mytilus edulis and the seaweed Fucus vesiculosus, (2) the importance of protected microhabitats to the survival of the main intertidal species and (3) the variation in species interactions in crevices of different shapes.

\section{STUDY AREA}

The study was carried out during 1980 and 1981 at Capucins on the south shore of the Northwestern Gulf of St. Lawrence $\left(49^{\circ} 03^{\prime} \mathrm{N}, 66^{\circ} 51^{\prime} \mathrm{W}\right.$; Fig. 1). In this region, the coastline is regular and exposed to wave action and severe ice abrasion. This site was selected for study because the shore is gently-sloping and it offers 2 very contrasting habitats, namely smooth horizontal surfaces and a variety of crevices of different sizes and shapes (Fig. 2).

In the study area, the intertidal zone is usually covered by shore ice (an upper and lower strand icefoot) from late November to April (El-Sabh 1979).
However, periods of ice formation and breakup vary from year to year. Considerable ice scouring occurs along the south shore of the Estuary because of the prevailing winds from the north-east. A detailed description of winter conditions and their effects on intertidal organisms are given for the study area by Bergeron \& Bourget (1984) and Bourget et al. (1985). The intertidal community is described by Archambault \& Bourget (1983).

The tides in the study area are semi-diurnal with a mean amplitude of $2.5 \mathrm{~m}$ and the mean water level is $1.61 \mathrm{~m}$ above lowest water of spring tides (LWST; Canadian Hydrographic Service 1984).

\section{MATERIALS AND METHODS}

Substratum topography. Substratum topography was studied by a series of 7 transects each separated by a distance of $10 \mathrm{~m}$. Each transect was perpendicular to the shore and extended from low tide level to $2.1 \mathrm{~m}$ above LWST. The position of the first transect was randomly chosen from a $100 \mathrm{~m}$ wide region of shore. Surface topography was measured in $0.25 \mathrm{~m}^{2}$ quadrats placed at $2 \mathrm{~m}$ intervals on the same side of the transect line, except for sites where tide pools were covering more than $25 \%$ of the quadrat surface, in which case they were placed on the other side. Boulders or pebble zones were not sampled since they were unstable substrata. The height of each quadrat from a permanent reference point (bench-mark) was measured using a stadia rod and surveyor's transit.

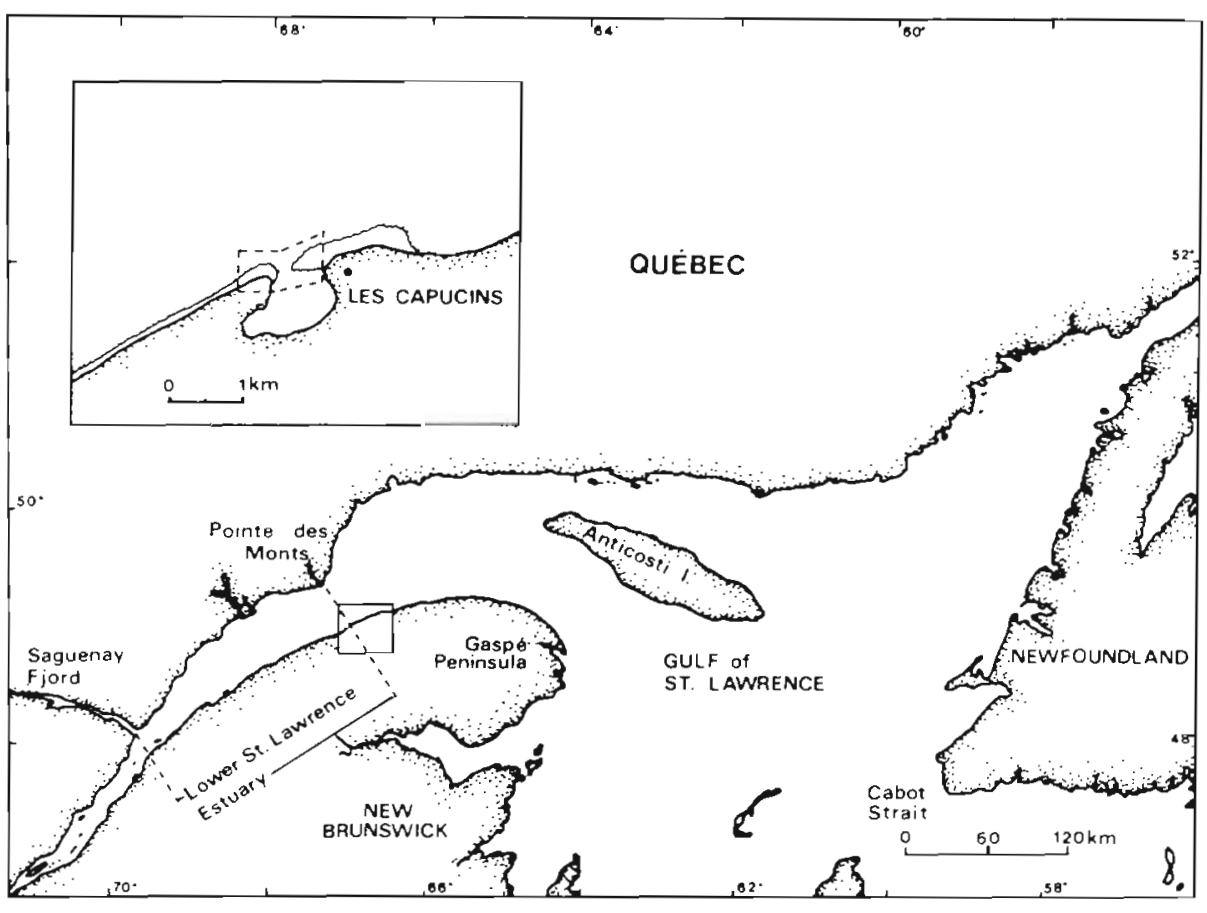

Fig. 1 Location of the study site at the estuary/Gulf of St. Lawrence boundary. Sampling area at Capucins is indicated by the dotted rectangle (inset) 


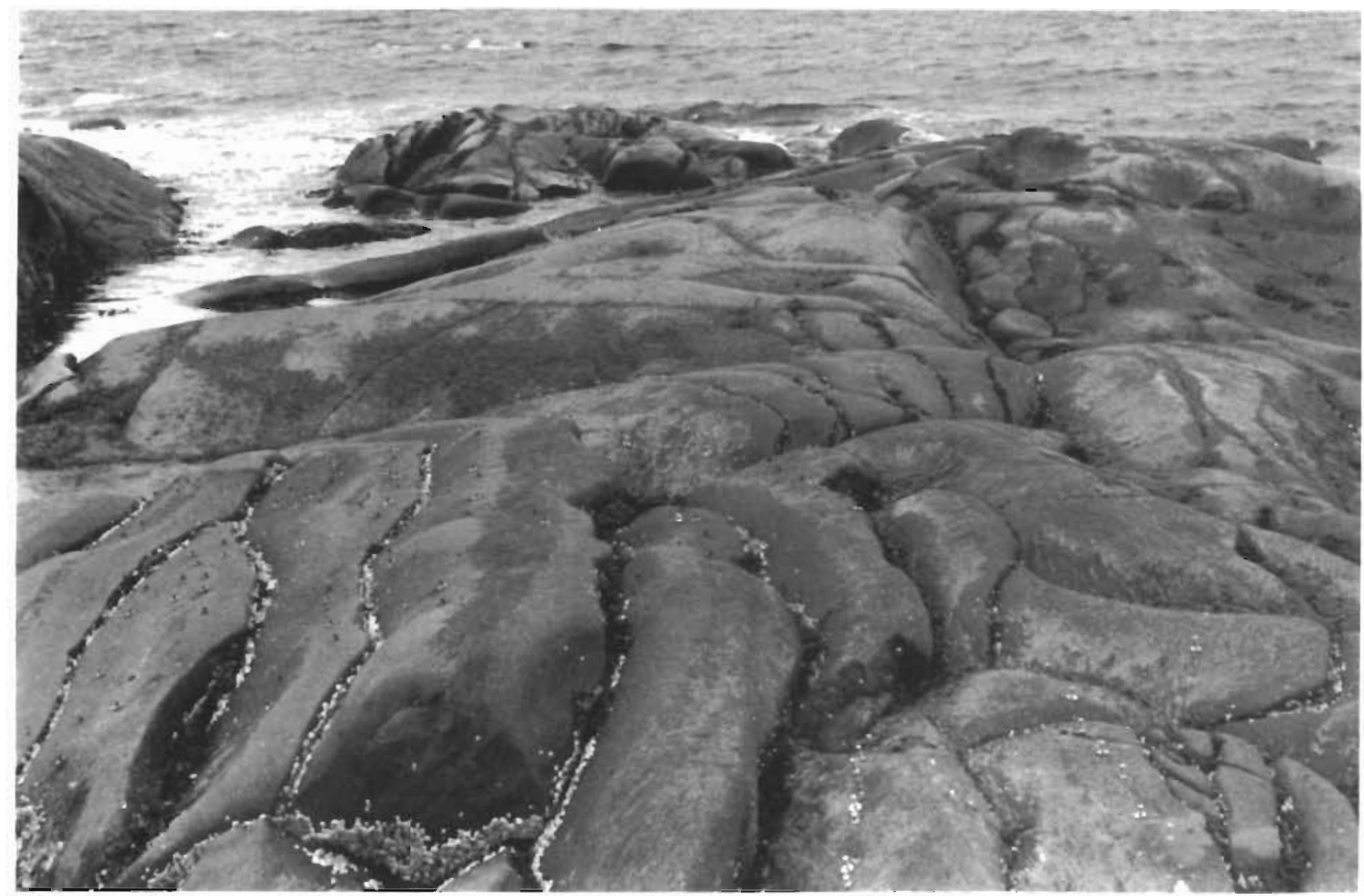

Fig. 2. A portion of the sampling area at Capucins. Note clear demarcation between smooth regular surfaces devoid of organisms (only screws fastened to the rock are seen), and crevices where sessile species are located

The physical parameters determined on the substratum were the linear distance along the surface $\left(\mathrm{L}_{\mathrm{A}}\right)$, the vertical height of each crevice and number of crevices (frequency). The measurements were determined along straight lines at $10 \mathrm{~cm}$ intervals across the quadrat frame. A total of 12 lines, 6 perpendicular and 6 parallel to the shoreline were studied so as to include crevices in either direction. For each line, the surface distance $\left(\mathrm{L}_{\mathrm{A}}\right)$ was measured by fitting a flexible measuring tape along the undulations of the substratum. This distance divided by the straight linear distance $(\mathrm{L}=50 \mathrm{~cm}$ ) was used as an index of surface irregularity ( $\mathrm{SI}=\mathrm{L}_{\mathrm{A}} / \mathrm{L}$ ) as formely used by Dahl (1973). Its value is 1.0 when the surface is flat and increases with surface irregularity or relief. Analogous methods have been used in studies on coral reef heterogeneity (Wellington 1982, Rogers et al. 1983).

The length of primary space occupied by each species along each of these lines was used to measure their relative abundances. Finally, the height of the crevice was measured from a line joining the upper limits of the crevice walls.

Crevice shape. The shape of each crevice was described by making 3 measurements of the following parameters: (1) crevice width measured as the distance between 2 opposing walls, (2) the angle of inclination (Angle $b$ ) of the crevice with respect to an horizontal plane and (3) the angle formed by the intersection of sidewalls (Angle a).

Microhabitat sampling. The distribution and abundance of sessile epibenthos were studied in the midintertidal zone (1.1 to $2.1 \mathrm{~m}$ above chart datum). Crevices were selected within a region of $400 \mathrm{~m}$ of shoreline and classified according to size and shape. Only crevices which had (1) a visual regularity and linearity of each sidewall, (2) absence of water, sediments and pebbles on the bottom and, (3) which were accessible for sampling were selected. For each crevice, geometric parameters were obtained at 2 or 3 points by carefully molding a fine metal wire along the sides and bottom of the crevice. A trace of each contour was drawn for later analysis.

In each crevice, height, cover and density of macroalgae and macroinvertebrates were obtained using a non-destructive technique: we placed a plastic sheet flat on each crevice wall and then traced, with permanent marking pens, the contour of barnacles and fucoid holdfasts, the general region of fucoid blade cover and the position occupied by mussels. Colours and symbols were used to distinguish between species and 
categories (juveniles, adults). Careful observations were made when drawing fucoid holdfasts and mussels to distinguish whether they were attached to the rock surface or to the parietal plates or operculi of barnacles. Photographs were taken seasonally to further document species distributions. From summer 1980 to autumn 1981, recruitment, growth and mortality were recorded seasonally on additional sheets overlaid on the initial drawings. The exact relocation of the plastic sheets was made possible by using screws fastened into 'rawl-plugs' in the rock.

Sampling was also carried out to monitor abundance and mortality on exposed substratum outside the crevices examined. The surface area examined was similar to that of the crevices. In April 1981, 6 additional crevices were selected to investigate barnacle settlement. The position of cyprids and early metamorphosed individuals were recorded on the plastic sheets. Recruitment and further survival, both inside and outside crevices, were examined at 2 to $3 \mathrm{~d}$ intervals (May 27 to June 10) and on 3 additional occasions until mid-August after which there was no further settlement.

Spatial pattern. The location and cover of each species, as mapped on the plastic sheets, were recorded using a GRAF/PEN sonic digitizer (SAC GP630). A 3 to $10 \mathrm{~cm}$ portion at the horizontal extremity of each crevice was eliminated to avoid edge effects. Maximum error for both $\mathrm{x}$ and $\mathrm{y}$ axes was $0.6 \mathrm{~mm}$. Data coding and sorting was done with a DMC-126 microcomputer (Cetec Corporation), while Fortran programs were used to calculate the cover area and vertical height of each species in the crevices. Abundance was calculated for juvenile and adult barnacles, fucoid holdfasts and thalli, mussels and bare rock firstly over the entire mapped surface, and secondly, at regular 1 inch $(2.54 \mathrm{~cm})$ intervals along randomly placed vertical transects. The number of replicate transects was varied in proportion to the crevice length $(N=5$ to 11$)$.

\section{RESULTS}

\section{Substratum heterogeneity}

Values of the surface index (SI) were calculated in 63 quadrats $\left(0.25 \mathrm{~m}^{2}\right)$ located in the mid-intertidal zone. Individual values ranged from 1.0 on smooth surfaces to 1.72 on irregular ones (Fig. 3). More than $70 \%$ of the samples had relatively regular surfaces with SI values of 1.0 to 1.09 . The most irregular transect had a SI of 1.72. Thus, at the spatial scale studied $(0.5 \mathrm{~m})$, the shore was characterized by regular smooth surfaces punctuated by occasional depressions (Fig. 2).

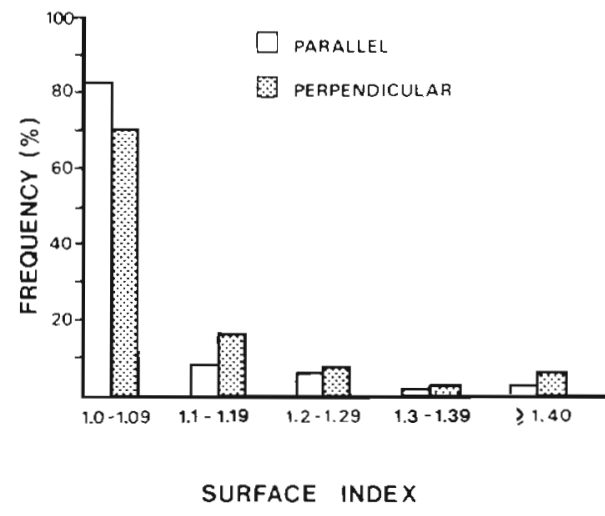

Fig. 3. Frequency of different surface indices ( $S I=L_{A^{\prime}} / L$, unitless) based on 6 parallel and 6 perpendicular measurements from 62 quadrats. Each increase of 0.1 unit of the index corresponds to a $5 \mathrm{~cm}$ increase in the actual surface length $\left(\mathrm{L}_{\mathrm{A}}\right)$ recorded. 'Parallel' and 'perpendicular' refer to orientation in relation to the shoreline

In order to examine the effect of substratum topography on species relative abundance, the surface index and frequency of crevices were used. Since the index is an estimate of the increase in the space available relative to a plane, linear measurements made for each species were weighted by dividing by the corresponding SI values. Thus, the relations obtained are functions of variations in the surface relief instead of merely being a reflection of the increase in space area. At low surface indices ( $\mathrm{SI}=1.0$ to 1.09 , crevice frequency $=0 ;$ Fig. 4), Mytilus edulis, Semibalanus balanoides and Fucus vesiculosus were least abundant $(<1 \mathrm{~cm})$. Mussels showed a strong increase in abundance at intermediate surface indices ( $\mathrm{SI}=1.2$ to 1.29 ), but a decrease at high surface indices ( $\mathrm{SI}>1.3$ ). In contrast, barnacle cover was low at surface indices of 1.0 to 1.3 and high at indices of 1.4 or more. Fucoid holdfasts were distributed more uniformly than mussels and barnacles and no clear trend was detected.

A low abundance of Semibalanus balanoides was observed when the abundance of Mytilus edulis was high. This was particularly evident when there was only 1 crevice per transect, in which case the increase in SI corresponds to an increase in crevice depth. Therefore, when there was only 1 crevice, its depth strongly affected the abundance of $M$. edulis and $S$. balanoides. While these data do not allow evaluation of species interactions, they clearly show the barrenness of smooth surfaces and the occurrence of the 3 species in crevices. Furthermore, this pattern of distribution appears to have been maintained all year long except in April when there was colonization of smooth surfaces by ephemeral algae (Ulothrix sp., Urospora sp.). There remained, however, marked variations in mussel and barnacle abundances due to patchiness in species distribution and to reduced 
Fig. 4. Semibalanus balanoides, Mytilus edulis, and Fucus vesiculosus. Mean relative abundance (linear distance in $\mathrm{cm}$ transect ${ }^{-1}$ ) as a function of surface index (SI) and frequency of crevices (mean number transect ${ }^{-1}$ ) along perpendicular (open bars) and parallel (hatched bars) profiles. Species abundances were weighted for the increase in transect length. Measurements for $F$. vesiculosus refer to length of holdfasts on the substratum. Sample sizes given below each bar; black rectangles indicate absence in sample. Vertical lines represent standard errors of the mean
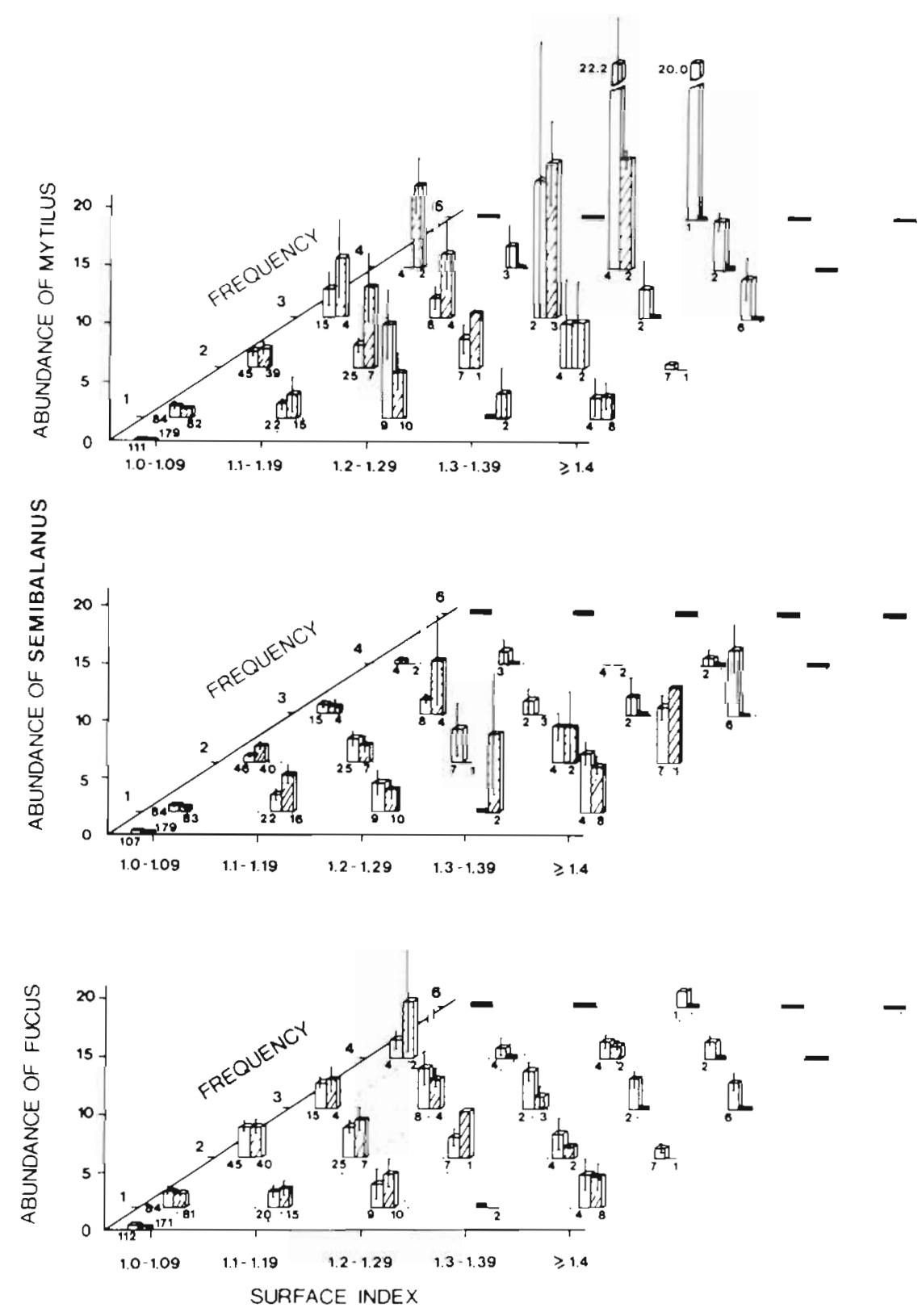

number of samples for intermediate and high surface indices.

\section{Spatial pattern within crevices}

To test the hypothesis that the degree of openness (width) of a crevice influences the distribution of sessile species, we made an analysis of the vertical distribution of species on crevice walls using all horizontal crevices where the angle of inclination (Angle b) was $\leqslant 10^{\circ}$. In addition, regularity of each crevice was evaluated using a complete linkage clustering technique based on the Gower coefficient calculated with
Angle $a$ and the width. Crevices with profiles not grouped together at a given similarity level $(S=0.70)$ were excluded. Thus only crevices of comparable geometry were used for the analysis.

Following this selection, 22 crevices were retained and for 5 of these, 1 portion (profile) of the crevice was eliminated. The crevices were then divided into 3 groups: narrow (angles $=40$ to $60^{\circ}$ ), intermediate (angles $=60$ to $90^{\circ}$ ) and wide (angles $=90$ to $120^{\circ}$ ) . The number of crevices in each group, their tidal height, and crevice length were similar, however the orientation of crevices in the second group differed from the other groups (Table 1). Each crevice sidewall 
Table 1 Tidal level, orientation and geometric parameters calculated for 3 groups of crevices selected along $400 \mathrm{~m}$ of shoreline at Baie des Capucins. Means and ranges

\begin{tabular}{|c|c|c|c|c|c|}
\hline $\begin{array}{l}\text { Crevice } \\
\text { angle }\end{array}$ & $\begin{array}{c}\text { Level } \\
\text { (m above chart } \\
\text { datum) }\end{array}$ & Orientation & $\begin{array}{l}\text { Length (L) } \\
\quad(\mathrm{cm})\end{array}$ & $\begin{array}{l}\text { Width (W) } \\
\qquad(\mathrm{cm})\end{array}$ & $\begin{array}{c}\text { Angle } \\
\text { (degree) }\end{array}$ \\
\hline $\begin{array}{l}\text { Narrow } \\
N=7\end{array}$ & $\begin{array}{c}1.69 \\
(1.4-2.0)\end{array}$ & $\begin{array}{l}5 \mathrm{E}-\mathrm{W} \\
2 \mathrm{~N}-\mathrm{S}\end{array}$ & $\begin{array}{c}45.9 \\
(33.5-58.3)\end{array}$ & $\begin{array}{c}13.4 \\
(9.3-18.0)\end{array}$ & $\begin{array}{c}51.4 \\
(40-60)\end{array}$ \\
\hline $\begin{array}{l}\text { Intermediate } \\
N=8\end{array}$ & $\begin{array}{c}1.61 \\
(1.4-1.8)\end{array}$ & $\begin{array}{l}2 \mathrm{E}-\mathrm{W} \\
6 \mathrm{~N}-\mathrm{S}\end{array}$ & $\begin{array}{c}43.0 \\
(33.0-55.6)\end{array}$ & $\begin{array}{c}22.7 \\
(14.9-29.0)\end{array}$ & $\begin{array}{c}74.3 \\
(64-90)\end{array}$ \\
\hline $\begin{array}{l}\text { Wide } \\
N=7\end{array}$ & $\begin{array}{c}1.73 \\
(1.5-1.9)\end{array}$ & $\begin{array}{l}5 \mathrm{E}-\mathrm{W} \\
2 \mathrm{~N}-\mathrm{S}\end{array}$ & $\begin{array}{c}40.4 \\
(32.0-50.3)\end{array}$ & $\begin{array}{c}30.7 \\
(24.0-41.8)\end{array}$ & $\begin{array}{c}102.1 \\
(92-116)\end{array}$ \\
\hline
\end{tabular}

was treated as a separate sample so that the numbers of surfaces in each angle category were respectively 14 , 16 and 14.

\section{Species zonation}

Using the data for summer 1980, upper and lower limits of each species were determined for each randomly located vertical transect. Semibalanus balanoides, Mytilus edulis and Fucus vesiculosus formed distinct bands along the sidewalls (Fig. 5A) and this zonation pattern was similar for the 3 groups of crevices. Mussels covered the bottom of crevices, adult barnacles and fucoid holdfasts occupied an intermedi- ate level on the sidewalls while the upper zone was devoid of macroscopic organisms. The algal canopy (not shown on Fig. 5A) slightly covered S. balanoides. Furthermore, barnacles and mussels overlapped over a small distance on the crevice wall and fucoid holdfasts were mostly confined to the upper half of the barnacle zone. Overlap of vertical range did not, however, always indicate physical overlap since the species could be separated horizontally. The proportions of $F$. vesiculosus holdfasts located on barnacle shells and on bare rock were respectively 67.8 and $32.2 \%$ ( $n=$ 171 ) in narrow crevices ( 40 to $60^{\circ}$ ) and 40.3 and $59.7 \%$ $(n=211)$ in 60 to $90^{\circ}$ crevices. The position of holdfasts in the wide angle category was not examined because
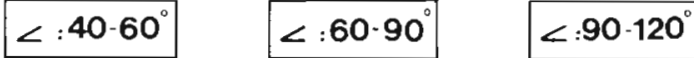
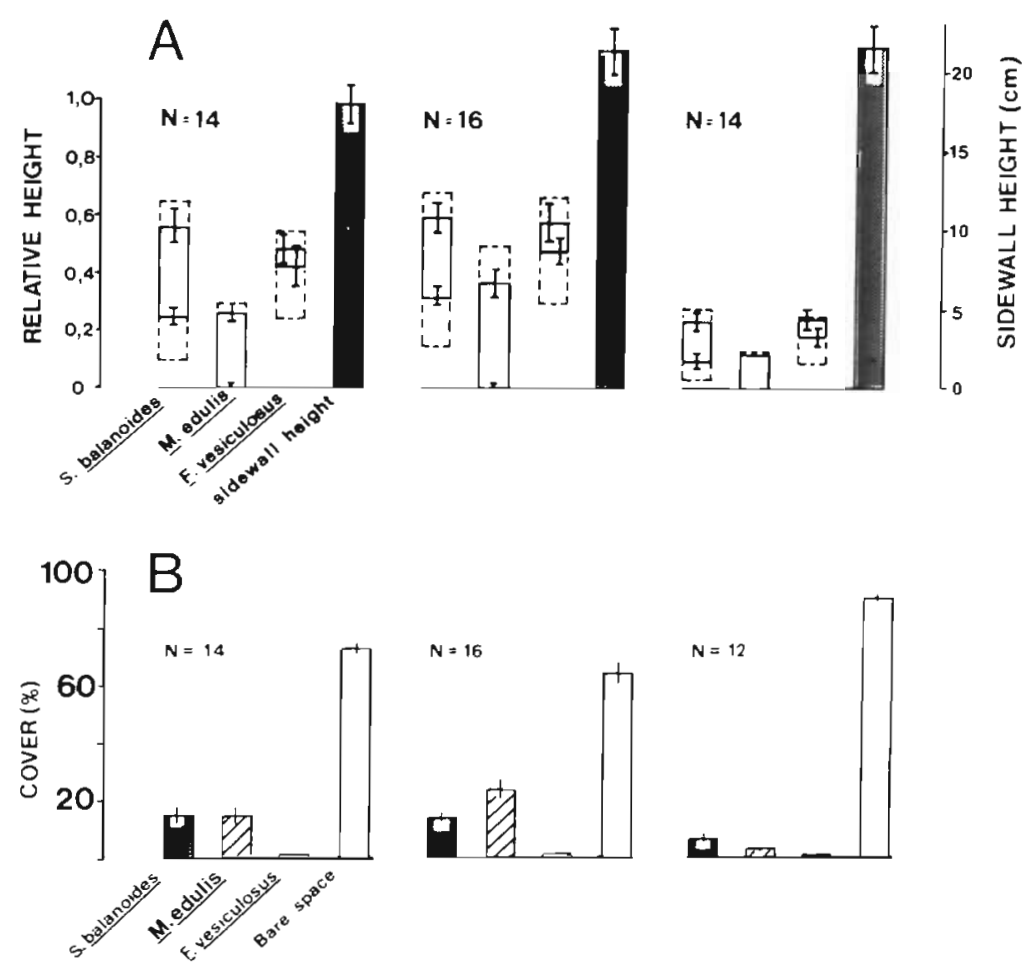

Fig. 5. Species distribution and abundance in crevices of different shapes, July 1980. (A) Distribution in relation to relative height and absolute sidewall height $(\mathrm{cm})$. Right ordinate refers to shaded bars only. Species zonation is presented as mean (solid line) $\pm \mathrm{SE}$ and maximum (broken line) upper and lower limits. $\mathrm{N}$ : total number of crevice walls in each group. (B) Species abundance calculated as species surface area relative to total sidewall area $(\%$ cover). Abundances presented as means ( \pm 1 $\mathrm{SE}$ ) of $\mathrm{N}$ surfaces in each group. In (A) and (B), Fucus vesiculosus measurements refer to holdfasts 
of the low number of plants. Mussels were most often seen packed between patches of barnacles and physical contact between species was thus minimal. With increasing cover of fucoids, barnacles were surrounded by mussels up to their operculi in the lower portion of the barnacle zone. Although in this case, direct interference with cirral beating was unlikely, further recruitment and growth of mussels might eventually have led to smothering of the barnacles. Finally, the least frequently observed situation was complete overgrowth of barnacles by mussels with attachment of their byssal threads to the operculi. In this case, the mussels probably interfered with the feeding of barnacles and this could result in barnacle mortality. In this situation, when mussels were removed, barnacle plates and empty barnacle shells were always found.

We further examined the sharpness of the upper and lower boundaries of Semibalanus balanoides and Fucus vesiculosus in crevices. For all 3 groups of crevices, the difference between mean and extreme upper limit was always smaller than between mean and extreme lower limit (Fig. 5). These differences were significant for barnacles in the 60 to $90^{\circ}$ crevices and for $F$. vesiculosus in crevices $>60^{\circ}$ (Wilcoxon's matched-pairs signed-ranks test, $\mathrm{P}<0.05$ ). The smallest differences were found for 90 to $120^{\circ}$ crevices and the largest differences for 60 to $90^{\circ}$ crevices.

\section{Effect of crevice shape}

The effect of crevice angle on the relative upper limit of species was tested with a multivariate analysis of variance (MANOVA, Nie et al. 1975). Treating the 3 angle categories as major groups and the different crevices within each group as nested random subgroups, Wilk's lambda coefficients were calculated for each source of variation. Relative height (ratio of species height to sidewall height) was normalized using the arcsin transformation. The homogeneity of equal variance-covariance matrices was tested using the Box's $M$ statistic $(M=176.0 ; F[96,2787]=1.24, P$ $>0.05)$ approximately distributed as an $F$ variate when $\mathrm{n}_{1}$ is small ( $<20$; Morrisson 1976). Relative upper limits of species were significantly different both between the 3 groups $(\lambda=0.24, F=11.67, P<0.01)$ and between the crevice walls within each group $(\lambda=0.10$, $\mathrm{F}=3.9, \mathrm{P}<0.01$ ).

A discriminant analysis was carried out to determine the relative contribution of the different species to the variation. Mussels accounted for most of the variability observed between groups, while both barnacles and mussels were responsible for changes in relative upper limits observed between crevice walls of each group (Table 2). Subsequent comparisons of means revealed
Table 2. Results of the discriminant analysis on the relative height of the 3 species for each significant effect in the nested MANOVA design. Standardized discriminant function coefficients and percent of separation are given

\begin{tabular}{|c|c|c|c|c|}
\hline \multirow[t]{2}{*}{ Effect } & \multirow[t]{2}{*}{ Species } & \multicolumn{3}{|c|}{$\begin{array}{l}\text { Discriminant } \\
\text { functions }\end{array}$} \\
\hline & & I & II & III \\
\hline \multirow{4}{*}{$\begin{array}{l}\text { Crevice } \\
\text { category }\end{array}$} & Semibalanus balanoides & -0.22 & 1.31 & - \\
\hline & Fucus vesiculosus & -0.43 & -0.61 & - \\
\hline & Mytilus edulis & -0.67 & -0.59 & - \\
\hline & $\%$ of separation & 90.3 & 9.7 & \\
\hline \multirow{4}{*}{$\begin{array}{l}\text { Crevices } \\
\text { (nested) }\end{array}$} & Semibalanus balanoides & 0.66 & -0.49 & 0.73 \\
\hline & Fucus vesiculosus & 0.30 & -0.13 & -1.05 \\
\hline & Mytilus edulis & 0.53 & 0.85 & 0.01 \\
\hline & $\%$ of separation & 52.9 & 32.3 & 14.8 \\
\hline
\end{tabular}

significant differences between the 3 types of crevices only for the upper limits of mussels ( $P<0.05$, Scheffé's test; Sokal \& Rohlf 1981). The upper limits of both barnacles and Fucus vesiculosus in the wide angled crevices were significantly different from those in the 2 other groups ( $\mathrm{P}<0.05$, Scheffé's test).

The relative size of each species' vertical range was examined using the ratio of its mean band width to maximum range over which there were organisms. For narrow and wide crevices, Semibalanus balanoides covered the greatest proportion of sidewalls ( $48.7 \%$ for narrow crevices and $46.3 \%$ for wide crevices), Mytilus edulis was second ( 40.9 and $37.3 \%$ respectively) and Fucus vesiculosus holdfasts third, covering only 10.4 and $16.4 \%$ respectively. In 60 to $90^{\circ}$ crevices, mussels occupied the greatest vertical range $(51.0 \%)$ and barnacles were second $(37.3 \%)$. Thus, the vertical range of the different species was not affected by different crevice angles except in 60 to $90^{\circ}$ crevices where the vertical range of mussels was extended. Here also, there was the greatest overlap in the vertical range of $M$. edulis and S. balanoides (Fig. 5A).

\section{Effect of sidewall height}

For the different groups of crevices, the height of the sidewall varied from 11.0 to $32.0 \mathrm{~cm}$. For a given crevice angle, we examined if sidewall height affected the limits of the species present and if this relation was constant for the 3 groups of crevices. Model II regressions (Ricker 1973) were calculated using sidewall height as the independent variable and mean upper limits as dependent variables (Fig. 6). While for $>90^{\circ}$ crevices there was no significant $(P>0.05)$ relation, for 40 to $60^{\circ}$ and 60 to $90^{\circ}$ crevices, associations between variables were significant $(P<0.05)$ indicating that 


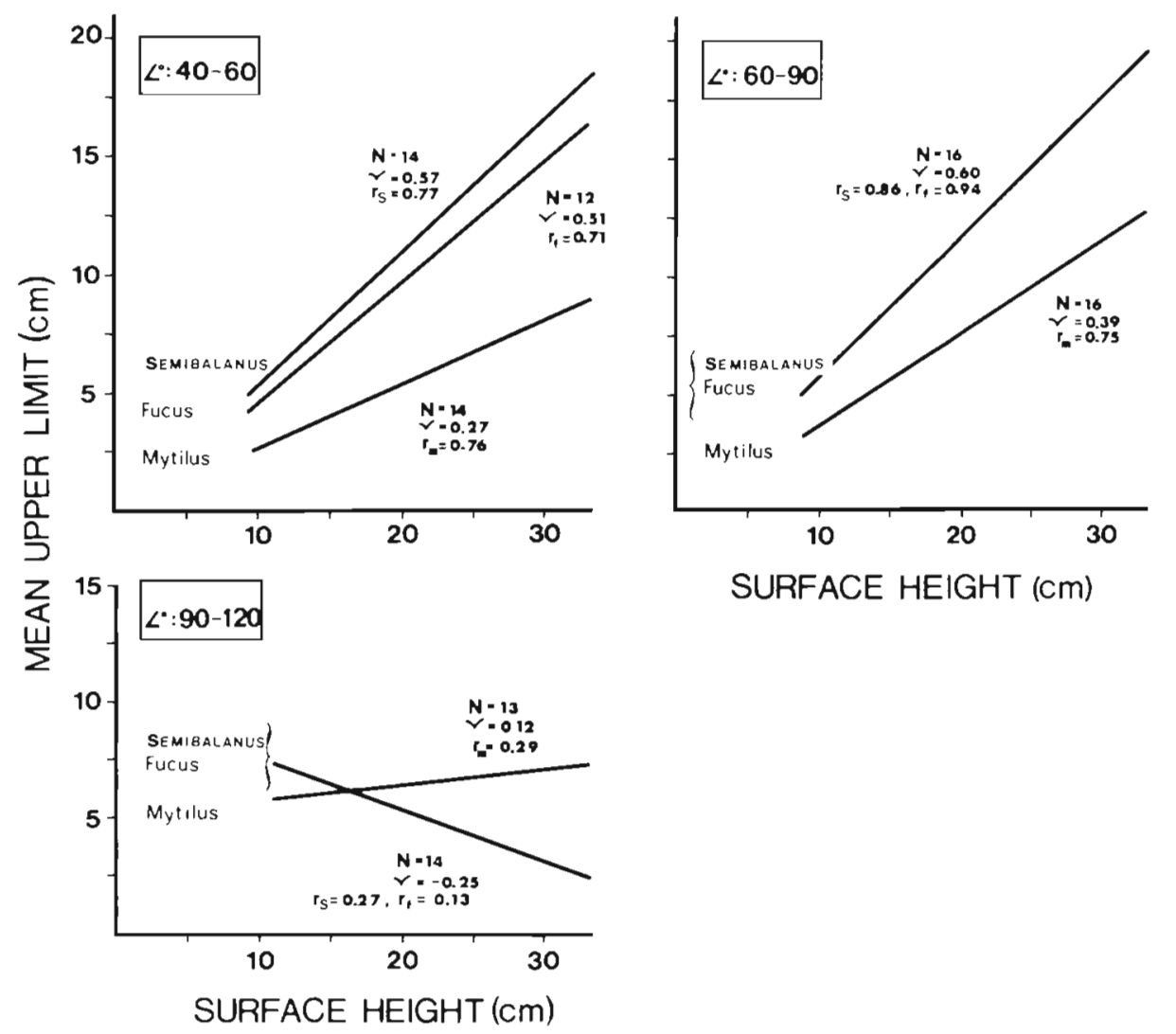

Fig. 6. Relation between species mean upper limit $(\mathrm{cm})$ and sidewall height $(\mathrm{cm})$ in narrow, medium, and wide crevices. Regression equations were obtained using Model II type (Geometric mean). This method is appropriate when both $X$ and $Y$ variables are subject to natural variability or measurement error (Ricker 1973). $N$ : number of surfaces analysed; $v$ : slope; $r$ : correlation coefficient. Subscripts of $\mathrm{r}: \mathrm{s}=$ Semibalanus balanoides; $\mathrm{m}=$ Mytilus edulis; $\mathrm{f}$ = Fucus vesiculosus. Significance of association between variables is tested using correlation coefficient (Ricker 1973; p. 413)

species height increased with sidewall height. In these last 2 groups, the upper limits of barnacles and of fucoid holdfasts showed a similar sharp rate of increase with sidewall height. The rate of increase for mussels was less and they extended higher on less steep walls (60 to $90^{\circ}$ crevices).

Thus, species were spatially segregated along the crevice walls and there was little overlap between Semibalanus balanoides and Mytilus edulis. Upper limits were strongly influenced by crevice shape, $M$. edulis being the most affected by changes in the angle between crevice walls. In contrast, the relative vertical ranges of the different species were similar for narrow and wide crevices. In the wide crevices, organisms were restricted to the bottom of crevices. Finally, species extended proportionately higher on the walls as absolute wall height increased for $<90^{\circ}$ crevices. This was more pronounced for barnacles and seaweed than for mussels.

\section{Species abundance within crevices}

Prior to examining species abundance in crevices, variations in the surface area of the sidewalls were compared for the 3 groups of crevices. No significant differences were detected $(F=0.82, P>0.05$,
ANOVA; Nie et al. 1975). Species cover in $\mathrm{cm}^{2}$ calculated on all surfaces of each group (see Materials and Methods') were expressed as a proportion of total area sampled (sidewall area; Fig. 5B). The proportion of bare space was $72.7 \%$ for 40 to $60^{\circ}$ crevices, $65.4 \%$ for 60 to $90^{\circ}$ crevices and $91.3 \%$ for 90 to $120^{\circ}$ crevices.

There was significant effect of crevice shape on the proportion of space occupied by each species as indicated by a MANOVA (Wilk's $\lambda=0.26, F[6,74]=$ 11.67, $\mathrm{P}<0.01$ ) on transformed data (arcsin transformation, Sokal \& Rohlf 1981; Box's $M=11.56, F[12$, $6436]=0.85, P>0.05)$. Again, discriminant function coefficients attributed much of this variability to Mytilus edulis.

The proportions of space occupied by Semibalanus balanoides and Mytilus edulis were similar in narrow crevices only. Mussels were almost twice as abundant as barnacles in the 60 to $90^{\circ}$ crevices while the inverse was true for wider crevices (Fig 5B). This corroborates well the vertical ranges reported above for these species (see Fig. 5A). As a result, the proportion of primary space where these 2 species overlapped was highest in the 60 to $90^{\circ}$ group $(\overline{\mathrm{X}} \pm \mathrm{SE}=2.8 \% \pm 0.6)$ and lower in narrower $(0.9 \% \pm 0.2)$ and wider $(0.1 \%$ $\pm 0.1)$ crevices. Thus, competitive interactions are most likely to occur in 60 to $90^{\circ}$ crevices and would here be limited to a small region at the mussel-bar- 
nacle boundary. In wide crevices, species cover was low, their vertical range more compressed and overlap between $S$. balanoides and $M$. edulis low.

The space occupied by mussels was also examined. In crevices where mussels were abundant and extended up to the barnacle zone, they formed a continuous cover on the bottom. Live individuals formed a mat 3 to $5 \mathrm{~cm}$ thick over a mixture of sediments, faeces and dead shells lying on the bottom of crevices. A large proportion were attached to one another without adhering to the rocky substratum. Mussels located nearest to the sidewall were more firmly attached to the rock surface or to barnacle shells. Individuals lying on the sediments were occasionally seen, in late autumn, forming hummocks.

\section{Seasonal variations in species abundance}

Temporal changes in total percentage cover of all major space-occupying species were examined in relation to crevice shape (Fig. 7). Almost no change in adult abundance occured during summer and autumn in all crevice groups, but there was a distinct reduction

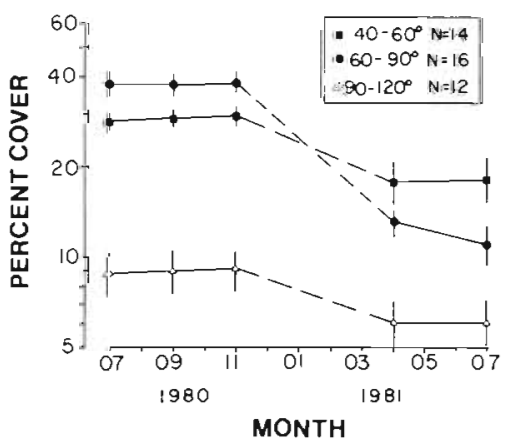

Fig. 7 Seasonal changes in total cover (\% of total area) in 3 groups of crevices. Cover values along the ordinate axis are presented on a $\log$-scale. Broken lines are used to indicate lack of samples due to ice cover on the shore

in abundance during the winter period (barnacle recruits were not included in calculations of cover area). Thus, the small increase in occupied space observed from July to November 1980 represented growth of adult barnacles and fucoid holdfasts (regeneration), as well as the extension of mussels up the sides of the crevices.

A 2-factor analysis of variance of these data showed the temporal changes to be highly significant $(\mathrm{P}<$ 0.01 , Table 3$)$, but there were no such effects $(P>0.05)$ for either the angle category or the interaction term. Thus, temporal changes in the 3 types of crevices were analogous during the whole study period. The results were further analyzed to determine when the changes
Table 3. Analysis of variance for the effect of seasons and crevice category on the proportion of total cover (Semibalanus balanoides + Fucus vesiculosus holdfast + Mytilus edulis cover: $\mathrm{cm}^{2}$ ) using a repeated measures design. Data were arcsin transformed. Assumption of additivity of treatment effect in cases of unreplicated data is verified with Tukey's test $(F=2.1, P>0.05$; Underwood 1981). Variation due to within error term is homogeneous (Fmax test, $P>0.05$; Winer 1971 p. 521). W indicates a nested factor

\begin{tabular}{|lrrc|}
\hline Source of variation & DF & MS & F \\
\hline Season & 4 & 0.142 & $5.68 \cdots$ \\
Crevice category & 2 & 0.211 & $1.34 \mathrm{~ns}$ \\
Season $\times$ category & 8 & 0.048 & $1.92 \mathrm{~ns}$ \\
Sample W category & 33 & 0.157 & - \\
Season $\times$ sample W & 132 & 0.025 & - \\
category & & & \\
(error within) & & & \\
$\cdots$ P $<0.01$; ns not significant & & & \\
\hline
\end{tabular}

in abundance occured. Multiple comparisons (StudentNewman-Keuls procedure; Sokal \& Rohlf 1981) of mean cover showed no significant seasonal changes in abundance $(\mathrm{P}>0.05)$ in narrow and wide crevices whereas, for 60 to $90^{\circ}$ crevices, the mean percent cover in 1981 seasons was significantly lower $(\mathrm{P}<0.05)$ than in the corresponding 1980 periods. Only 1 significant difference between seasonal mean cover was obtained because Student-Newman-Keuls tests are more conservative (or less powerful) than the F-ratio (Underwood 1981, p. 530). Thus, significant changes in percent cover within crevices were limited to the winter. Furthermore, crevice populations showing significant changes were those having the greatest initial cover of organisms (60 to $90^{\circ}$ crevices, see Fig. $5 \mathrm{~B} \& 7$ ).

Within each crevice category, the effect of winter disturbances varied for the different species. In all types of crevices, the reduction of occupied primary space was mostly due to mussel dislodgment (Table 4, line 1). Between 62 and $78 \%$ of the initial mussel cover was removed (Table 4, line 2 ). The remaining mussels were firmly secured to barnacle shells or to fucoid holdfasts and were usually located at the lower edge of the barnacle zone. Remnants of byssal threads were seen along crevice walls and never extended more than a few centimeters below the barnacles. This was because soft substrata previously occupied the bottom of crevices. The bottom of crevices was often bare (the community of only 3 out of 21 crevices remained intact), making the lower limit of the barnacle zone clearly visible, and defoliation of the algal canopy was apparent on the sidewalls (see Table 4). Barnacles were often pulled off the substratum when we experimentally removed the algal canopy and it is conceivable that removal of Fucus vesiculosus by physical 
Table 4. Changes in cover from Nov 1980 to Apr 1981, expressed as a proportion (\%) of (1) the total area sampled and (2) of species initial cover in Nov 1980. Data are means $\pm(1 \mathrm{SE})$ for each category of crevices. Juvenile barnacles are not included in calculations

\begin{tabular}{|c|c|c|c|c|c|}
\hline \multirow{3}{*}{ Category } & & \multicolumn{4}{|c|}{ Species } \\
\hline & & \multirow[t]{2}{*}{ Semibalanus balanoides } & \multirow[t]{2}{*}{ Mytilus edulis } & \multicolumn{2}{|c|}{ Fucus vesiculosus } \\
\hline & & & & (Holdfast) & (Frond) \\
\hline \multirow[t]{2}{*}{$40-60^{\circ}$} & 1 & $2.5(2.0)$ & $9.3(8.5)$ & $0.2(0.2)$ & $11.6(10.9)$ \\
\hline & 2 & $23.7(5.4)$ & $68.9(9.2)$ & $42.5(8.4)$ & $72.5(10.5)$ \\
\hline \multirow[t]{2}{*}{$60-90^{\circ}$} & 1 & $3.9(2.7)$ & $20.8(14.3)$ & $0.3(0.3)$ & $32.4(24.7)$ \\
\hline & 2 & $28.4(4.2)$ & $78.1(8.9)$ & $30.0(6.8)$ & $77.4(8.6)$ \\
\hline \multirow[t]{2}{*}{$90-120^{\circ}$} & 1 & $1.5(1.4)$ & $1.9(1.0)$ & $0.2(0.3)$ & $12.2(9.6)$ \\
\hline & 2 & $25.9(4.5)$ & $62.3(10.1)$ & $29.3(8.9)$ & $68.3(7.8)$ \\
\hline
\end{tabular}

factors would also remove barnacles, a phenomenon previously recorded by Hardwick-Witman (1985) in an ice-affected salt marsh where $F$. spiralis grew on the mussel Geukensia demissa. The disappearance of barnacles accounted for only 1.5 to $3.9 \%$ of the space freed during the winter and mortality was 23 to $28 \%$ (Table 4 , line 2). By contrast, the mortality of seaweed and mussels was much higher. Thus, Semibalanus balanoides (adults) was the least disturbed species even though it occurred highest on crevice walls.

The rate of barnacle and mussel mortalities at different height on crevice walls was also examined (Fig. 8). The reduction in cover was calculated at each $2.54 \mathrm{~cm}$ interval (= 1 inch stratum) along replicate vertical transects (see 'Material and Methods'). For each category of crevice, sidewalls with equal number of strata (equal height) were pooled into 4 groups $(6,8,9$ and 12 strata). Mortality values (reduction in \% cover) between strata were compared using the Kruskal-Wal- lis test (a non-parametric analogue to 1-way ANOVA; Sokal \& Rohlf 1981). Only 1 out of 12 tests (4 heights $\times 3$ crevice categories) gave a significant difference in mortality at different heights $(\mathrm{H}=18.8, \mathrm{n}=112$; $\mathrm{P}<$ $0.01)$. Thus mortalities were similar whatever positions barnacles occupied - either alone on the upper third of the sidewall or on the lower part together with mussels. Thus, in 1981, differential adult mortality was apparently not the mechanism responsible for setting upper and lower limits of barnacles.

\section{Settlement and recruitment patterns of Semibalanus balanoides}

In 1980, settlement of Semibalanus balanoides in the mid-intertidal zone began on June 2. Most individuals settled during June and none were observed settling after July 25. In 1981, larvae and spat (total 502 indi-
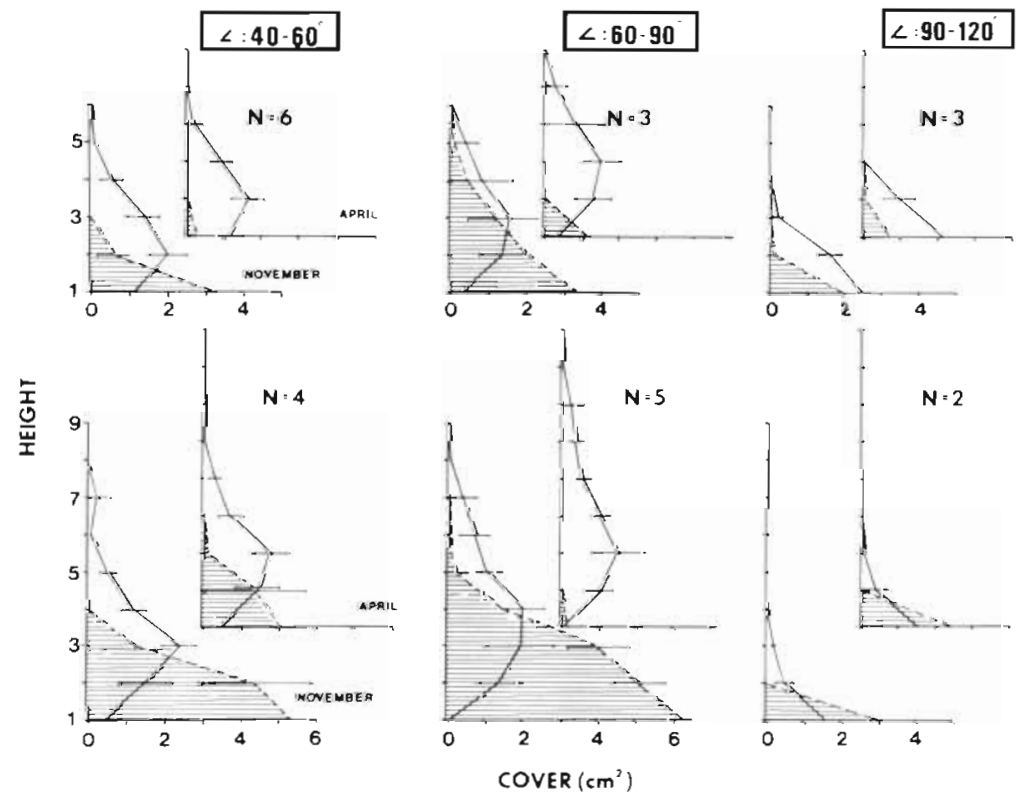

Fig. 8. Changes in mussel (hatched areas) and barnacle cover (open areas, $\mathrm{cm}^{2}$ ) as a function of sidewall height between Nov 1980 and Apr 1981. Data for only 2 heights of sidewall ( 6 and 9 strata, each stratum being $2.54 \mathrm{~cm}$ in height). Juvenile barnacles recruited during summer 1980 not included in Nov values. Abundance presented as mean ( $\pm 1 \mathrm{SE}$ ) surface area $\left(\mathrm{cm}^{2}\right.$ ) per $6.45 \mathrm{~cm}^{2}$ quadrat $(2.54 \times 2.54 \mathrm{~cm}) . \quad \mathrm{N}$ : number of sidewalls. $(100 \%$ cover equals $\left.6.45 \mathrm{~cm}^{2}\right)$ 


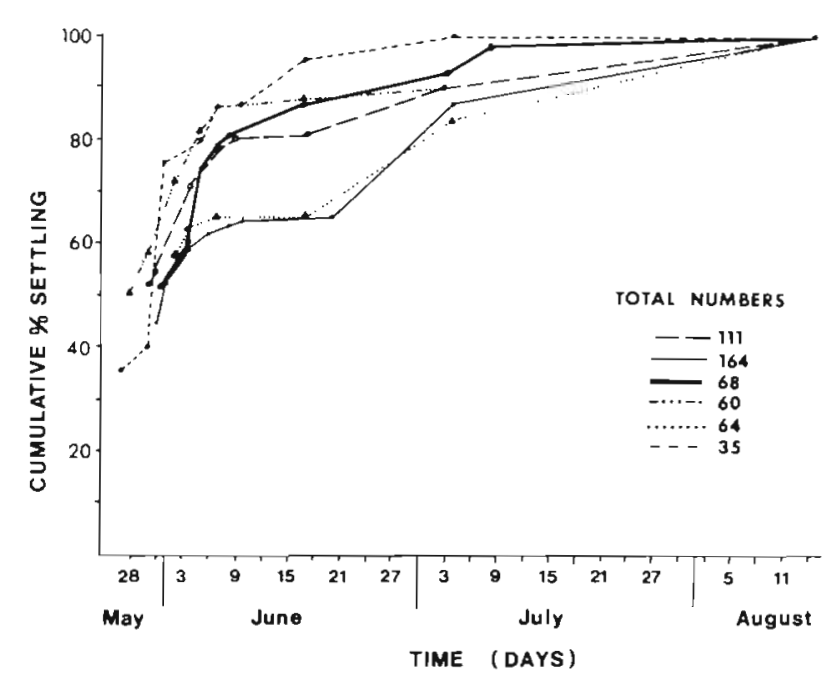

Fig. 9. Semibalanus balanoides. Settlement in 6 mid-intertidal crevices from 27 May to 15 Aug 1981. Crevices with angle 60 to $90^{\circ}$

viduals) in 6 crevices were counted at different dates from the onset of settlement (May 25) until mid-August (Fig. 9). More than $50 \%$ of recruitment occurred during the first $6 \mathrm{~d}$ of settlement. By early July, this proportion had reached 85 to $100 \%$. Between 28 May and 10 June, at the time of peak barnacle settlement, only $47.1 \pm 1.9 \%(\overline{\mathrm{X}} \pm \mathrm{SE} ; \mathrm{N}==136)$ of cyprids had metamorphosed. After metamorphosis, spat survival was much higher as more than $96.8 \pm 1.2 \%$ were still present on August 15, 1981

In addition to survival data, the spatial positions of cyprid larvae and spat were recorded. The mean proportion of individuals settling inside crevices was 97.0 $\pm 0.1 \%(\mathrm{~N}=474 ; 1981)$. On crevice sidewalls, cyprids were more numerous immediately around patches of barnacles but were rarely found touching the edge of adult shells. Those that settled directly on adult shell plates represented only $1.69 \%(\mathrm{~N}=474 ; 1981)$. Positions of newly metamorphosed cyprids on all crevice walls (42 surfaces within the 3 categories) were also analysed to determine the influence of adult distribution. In 1980, the maximum heights where spat and adults occured were not significantly different for all 3 crevice groups (Table 5). In addition, the mean proportion of juveniles located above the upper limit of adult barnacle was only $8.2 \pm 1.9 \%(\overline{\mathrm{X}} \pm 1 \mathrm{SE} ; \mathrm{n}=1074$ individuals, all 42 sidewalls pooled). In 40 to $60^{\circ}$ and 60 to $90^{\circ}$ crevices, mussels were present in the lower part just below the barnacle zone and newly-settled barnacle were significantly ( $P<0.05$ and $\mathrm{P}<0.001$ ) higher than conspecific adults by a mean height of 1.7 to $2.3 \mathrm{~cm}$. However, in wide crevices, mussels usually did not form a continuous cover on the bottom of crevices and settlement occured closer to the lower limit of adults.

In contrast to spring 1980, in spring 1981 space was available for settlement below the lower limit of adult barnacles because of the absence of mussels. The mean proportion of spat observed below the adult zone was $19.8 \pm 3.8 \%(\bar{X} \pm 1 \mathrm{SE} ; \mathrm{N}=610,3$ categories of crevices pooled). By contrast, barnacles located above the maximum upper limit of adults represented on average only $5.7 \pm 1.8 \%$ even though the amount of unoccupied space at that level was significantly higher than surfaces freed by mussels $\left(\bar{X}=425.1 \mathrm{~cm}^{2}\right.$ and $143.5 \mathrm{~cm}^{2}$, Wilcoxon's signed-ranks test, $\mathrm{P}<0.001$ ). Thus, the majority of the remaining spat were within the vertical range occupied by adults.

The density of recruits was evaluated at the end of each settlement season (August 1980, 1981) in all crevices (i.e. 42 surfaces $=$ a total sampling area of $3.74 \mathrm{~m}^{2}$ ). Since a negligible proportion of spat was found on adult barnacle shells and none occurred on seaweed holdfasts and mussels, the total free area at

Table 5. Wilcoxon's matched-pairs signed-ranks test (Sokal \& Rohlf 1981) on maximum and minimum heights occupied by adult barnacles and spat in the 3 angle categories. Values are mean $(\mathrm{cm}) \pm 1$ SE of all surfaces within each group. Wilcoxon's $T$ and the probability level (2-tailed) obtained are given. Data refer to the spring 1980 settlement

\begin{tabular}{|c|c|c|c|c|c|c|}
\hline \multirow{2}{*}{$\begin{array}{l}\text { Crevice } \\
\text { category }\end{array}$} & \multicolumn{3}{|c|}{ Maximum height } & \multicolumn{3}{|c|}{ Minimum height } \\
\hline & Adults & & Spat & Adults & & Spat \\
\hline \multirow[t]{3}{*}{$40-60^{\circ}$} & \multirow{3}{*}{\multicolumn{2}{|c|}{$\begin{array}{l}\mathrm{T}=50.0 \\
\mathrm{P}=0.900 \mathrm{NS}\end{array}$}} & $11.49 \pm 1.12$ & $1.68 \pm 0.42$ & & $3.4 \pm 0.72$ \\
\hline & & & & & $T=14.0$ & \\
\hline & & & & & $P=0.013^{\circ}$ & \\
\hline \multirow[t]{3}{*}{$60-90^{\circ}$} & \multirow[t]{3}{*}{$14.94 \pm 1.23$} & & $15.47 \pm 1.20$ & $2.73 \pm 0.52$ & & $5.06 \pm 0.65$ \\
\hline & & $\mathrm{T}=57.0$ & & & $\mathrm{~T}=6.0$ & \\
\hline & & $P=0.597 \mathrm{NS}$ & & & $P=0.0004^{\cdots}$ & \\
\hline \multirow[t]{3}{*}{$90-120^{\circ}$} & \multirow[t]{3}{*}{$6.23 \pm 1.01$} & \multirow{3}{*}{\multicolumn{2}{|c|}{$\begin{array}{l}\mathrm{T}=23.0 \\
\mathrm{P}=0.233 \mathrm{NS}\end{array}$}} & $0.70 \pm 0.48$ & & $1.13 \pm 0.37$ \\
\hline & & & & \multirow{2}{*}{\multicolumn{3}{|c|}{$\begin{array}{l}\mathrm{I}=16.0 \\
\mathrm{P}=0.496 \mathrm{NS}\end{array}$}} \\
\hline & & & & & & \\
\hline$\cdot P<0.05$ & $\because \mathrm{P}<0.01$ & nificant & & & & \\
\hline
\end{tabular}


time of settlement was taken as potential area for settlement. Overall mean recruitment (spat) densities were 0.05 ind $\mathrm{cm}^{-2} \pm 0.01 \mathrm{SE}$ (1980) and 0.02 ind $\mathrm{cm}^{-2}$ $\pm 0.005 \mathrm{SE}$ (1981). The maximum value recorded in a crevice was 0.35 ind $\mathrm{cm}^{-2}$. As mentioned earlier, there was high spat survival during summer (1980 and 1981), so these densities were considered representative of the initial spat number. Considering the low densities obtained, early mortality (after 5 to $6 \mathrm{mo}$ ) due to intraspecific crowding was unlikely.

\section{Mortality of juveniles and maintenance of barnacle population}

In 7 selected areas on horizontal surfaces (total sampling area ca $20 \mathrm{~m}^{2}$ ), 63 individuals were counted in November 1980 . Only $8.5 \%$ of the individuals were present the following spring. Since newly metamorphosed individuals survived well during summer, we also examined winter survival (November 1980 to April 1981) of juveniles along crevice sidewalls (Fig. 10). Juvenile survival in crevices was examined as for adult barnacles and was markedly higher than outside crevices. However, it also appeared to vary at different heights on crevice walls. Juvenile mortality was significantly higher in the uppermost portion of the crevice in 3 out of 10 tests (Table 6). The strata in 2 groups could not be compared due to low sample size. In 5 other cases, in the 2 uppermost strata barnacle mortality was higher but not significantly so $(P>0.05)$. When there was no significant height effect on juvenile mortality, the mortalities - though variable at the same stratum - were generally similar to those calculated for adults located at a same height.

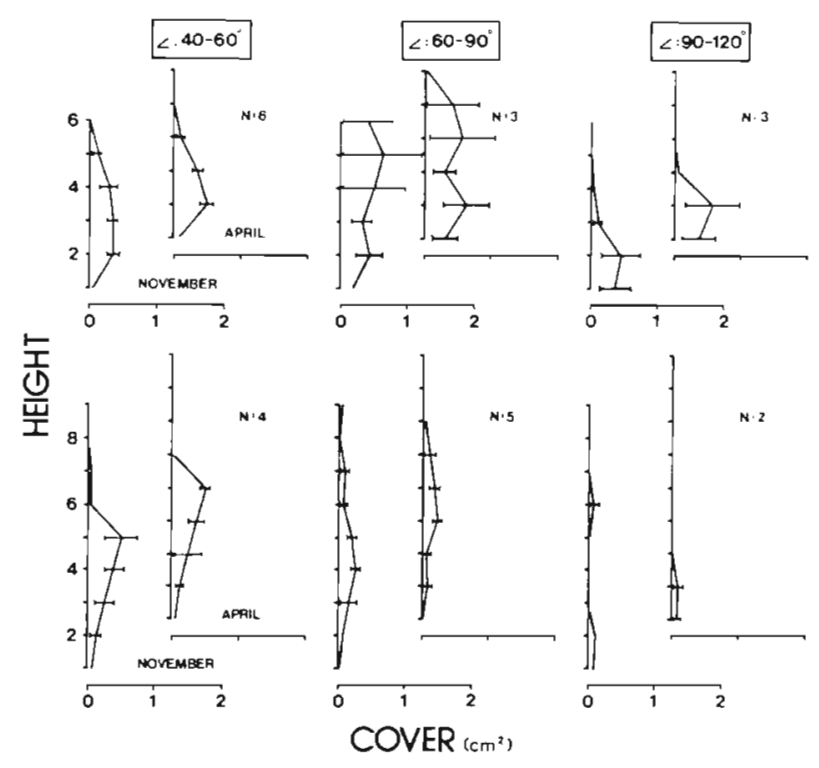

Fig. 10. Semibalanus balanoides. Changes in cover $\left(\mathrm{cm}^{2}\right)$ of juvenile barnacles as a function of height (number of strata) on sidewall between Nov 1980 and Apr 1981. Data for each category of crevice and 2 heights of sidewall ( 6 and 9 strata; 1 stratum $=2.54 \mathrm{~cm})$. Height, cover values and number of crevices are as in Fig. 8. (100\% cover equals $\left.6.45 \mathrm{~cm}^{2}\right)$

One would expect mortality to increase with an increase in the angle between crevice walls. For most wide crevices, comparisons could not be made for higher positions on the walls due to lack of recruitment. However, for those that were colonized at upper levels (Table 6, column 3), significantly higher mortality occurred in the upper portion of crevices. Surprisingly, for 40 to $60^{\circ}$ crevices there was 70 to $100 \%$ mortality in the uppermost stratum while, for 60 to $90^{\circ}$ crevices, there was only 30.9 to $45.5 \%$ mortality at

Table 6. Kruskal-Wallis test comparing winter mortalities of juvenile barnacles between strata within crevices of similar height $(6,8,9$ and 12 strata). Included in the analyses are only those strata (in parentheses) where juveniles were present in fall 1980. Positions of strata compared (stratum $1=$ bottom, stratum $12=$ highest position), total number of quadrats (N) and the statistic $\mathrm{H}$ are given. Sets of strata that were significantly different $(\mathrm{P}<0.05)$ following multiple comparisons (Conover $1980 \mathrm{p}$. 232) are indicated

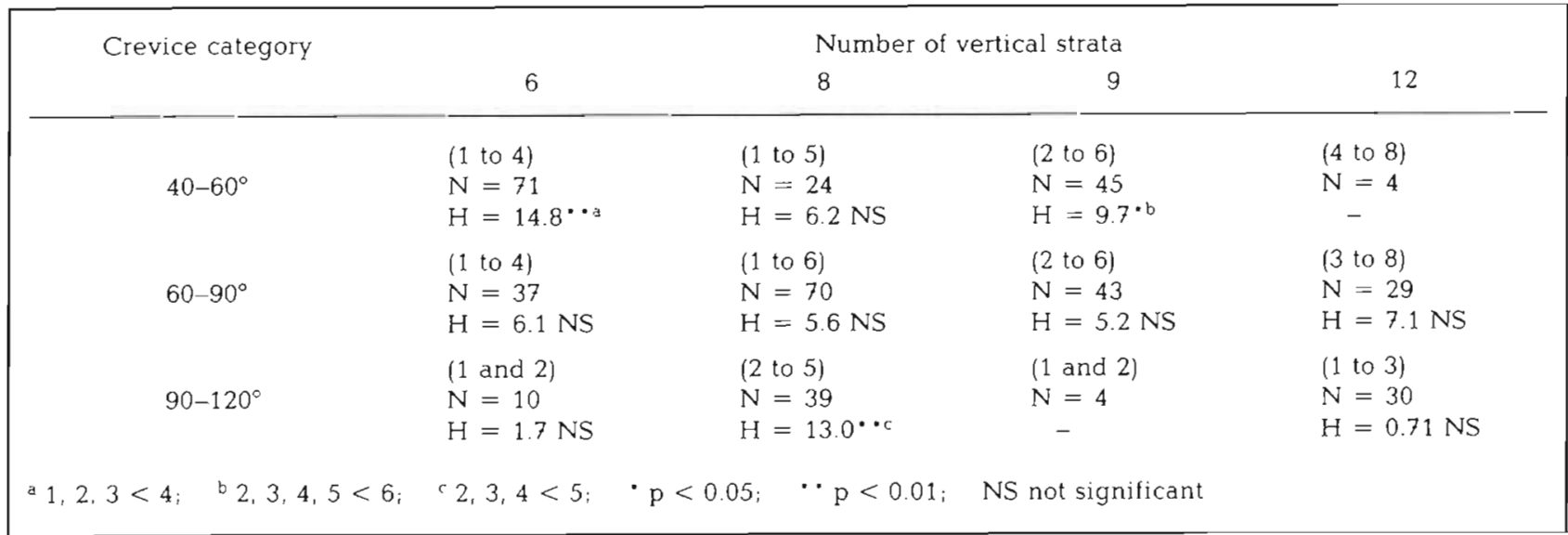


Table 7 . Proportion (mean \% \pm 1 SE) af total barnacle cover on sidewalls accounted for by juveniles (JUV) after 1 (Nov 1980 ) and 2 (Sep 1981) growth seasons and by adults (1980 cohort; A) in each category of crevices. The last column refers to proportion of adult cover lost during winter (from Table 4). N: number of sidewalls

\begin{tabular}{|cccccc|}
\hline $\begin{array}{c}\text { Crevice } \\
\text { category }\end{array}$ & 1980 & & & 1981 & \\
& JUV & JUV & JUV + A & \% Adult lost \\
\hline \multirow{2}{*}{$40-60^{\circ}$} & $19.4(15.0)$ & $7.5(10.4)$ & $21.5(16.3)$ & $29.0(22.3)$ & $23.7(5.4)$ \\
& $\mathrm{N}=14$ & $\mathrm{~N}=14$ & $\mathrm{~N}=14$ & $\mathrm{~N}=14$ & $\mathrm{~N}=14$ \\
$60-90^{\circ}$ & $20.1(16.5)$ & $12.7(10.0)$ & $20.6(14.4)$ & $33.3(18.6)$ & $28.4(4.2)$ \\
& $\mathrm{N}=16$ & $\mathrm{~N}=16$ & $\mathrm{~N}=16$ & $\mathrm{~N}=16$ & $\mathrm{~N}=16$ \\
$90-120^{\circ}$ & $28.9(16.4)$ & $7.7(6.2)$ & $30.1(17.4)$ & $37.5(22.0)$ & $25.9(4.5)$ \\
& $\mathrm{N}=12$ & $\mathrm{~N}=10$ & $\mathrm{~N}=12$ & $\mathrm{~N}=10$ & $\mathrm{~N}=12$ \\
\hline
\end{tabular}

upper levels. Differences in the orientation of crevices (Table 1) or spatial variations in ice distribution and movement might account for this difference.

Thus, reduced settlement above the adult zone (Table 5, Fig. 10) or higher mortality during winter for juveniles settled above barnacles (Table 6, Fig. 10) might explain the upper limit of barnacles.

Overall juvenile mortalities were $12.3 \%$ (SE \pm $5.0 \%$ ) in narrow crevice, $20.5 \%$ (SE $\pm 6.2 \%$ ) in intermediate crevices and $15.5 \%(\mathrm{SE} \pm 8.7 \%$ ) in wide crevices. These mortality distributions were not significantly different from the corresponding adult mortalities calculated in Table 4 for the same crevice categories (Mann-Whitney U-test, $\mathrm{P}>0.05$ ). To determine the relative importance of juvenile barnacle mortalities to the space occupied by barnacles, we evaluated in September 1981 the proportion of total barnacle cover represented by juveniles ( $<1$ yr old) and adults (1980 cohort, $1+$ yr old; Table 7). The proportion of barnacle cover represented by juveniles at the end of the first growing season (1980) was also calculated. Since sampling was carried out earlier in 1981, juveniles recruited during 1981 may have contributed less to cover than those recruited in 1980. In 1980 , juveniles reached 20 to $30 \%$ of total barnacle cover and maintained this level the following year, thus approximately replacing winter adult mortality. Thus, the space occupied by barnacles is stable and gains due to recruitment and growth are compensated by losses due to adult mortality.

\section{DISCUSSION}

Our objectives were to examine the distribution patterns of the 3 dominant species Semibalanus balanoides, Mytilus edulis and Fucus vesiculosus in a location exposed to harsh winter conditions and annual ice abrasion and further to elucidate the factors responsible for the patterns observed. Two major points were considered, the overall distribution in relation to substratum irregularities, and space partition- ing between these dominants within crevices in the mid-intertidal zone.

Substratum relief (at the $0.5 \mathrm{~m}$ scale) strongly influences species abundances. All 3 dominant species are virtually limited to cracks and crevices and nearly absent on smooth horizontal surfaces. The increase of abundance with increasing heterogeneity is not linear but rather each species attains a maximum at a given heterogeneity level. This could be due either to species interactions or to differential success of the species related to the shape of depressions and crevices.

A number of hypotheses may explain why the intertidal dominants are limited to crevices and why they were zoned along crevice walls: (1) differential settlement of larvae; (2) differential mortality of larvae or adults; (3) a combination of these factors. Our analysis of species distribution and seasonal variations in abundance within and outside crevices permits us to test the validity of these hypotheses.

\section{Differential settlement of barnacles}

Cyprid larvae settled in far greater proportion inside crevices $(97.0 \%)$ than on adjacent exposed surfaces and they survived well during the summer. Within crevices, larvae do not colonize all available space but mainly a zone near the adults. In both years, a small proportion ( $<8.2 \%$ ) of larvae settled above the adult zone. When mussels are present on the bottom of crevices there is no barnacle settlement there. However, when mussels are dislodged, there is settlement on the bottom. In fact the settlement is greater than above the adult barnacle zone (19.8 vs $5.7 \%$ ) even though the space availability is less. The absence of barnacle settlement when mussels are present indicates that mussels somehow prevent barnacle settlement. Therefore, barnacle larvae did not only avoid exposed outside surfaces but they also showed reduced settlement above the adult zone on sidewalls. Thus barnacles selectively settle in crevices. 
We did not test whether selective settlement in crevices is related to active discrimination by larvae or to hydrodynamical factors (e.g. Water flow in crevices vs exposed surfaces). However, it has been demonstrated that barnacle larvae select sites near adults (gregarism; see Crisp 1974). This suggests that the observed settlement in crevices could merely be due to the presence of adults there.

\section{Factors affecting limits of distribution in crevices}

\section{Upper limit of barnacles}

The virtual failure of barnacle larvae to settle on exposed surfaces is primarily responsible for their absence there. Outside crevices, the few barnacles that settled during summer almost entirely disappeared during wintertime $(91.5 \%, \mathrm{~N}=63)$, most probably killed by ice scouring. Within crevices, the low settlement of larvae above the adult zone and increased juvenile mortality due to ice (mechanical effect) in this zone set the upper limit of barnacle distribution. These conclusions are comparable to those of Denley \& Underwood (1979) who showed that lack of settlement was responsible for setting the upper limit of Tesseropora rosea and Tetraclitella purpurascens on the shores of New South Wales. Further, uniform mortality of adults along the sidewalls and low summer mortality of spat suggest that the upper limit of $S$. balanoides in crevices is not associated with desiccation conditions such as those described by Connell (1961), Luckens (1970), Foster (1971) and Wethey (1983) in the upper intertidal zone.

Ice kills a high proportion of barnacle individuals outside crevices and above the upper limit of adults in crevices. Since only a small proportion of individuals settled there, overall annual mortality of barnacle due to ice scouring remains much lower than anticipated. This situation contrasts sharply with that observed on the New England coast where ice-related mortality is high at similar shore levels when ice covers the shore (Wethey 1979)

Lower limit of barnacles and upper limit of mussels

The abundance of Mytilus edulis and Semibalanus balanoides in relation to the heterogeneity index indicates the 2 species may interfere in their utilization of primary space. Further evidence of an interaction is present in crevices where $M$. edulis occupied the greatest vertical range of sidewall (angles $=60$ to $90^{\circ}$ ) since in those crevices the width of the barnacle band is reduced and there is the greatest overlap between both species.
Our data show that when mussels completely cover the bottom of crevices, barnacle settlement is prevented. In contrast, when mussels suffer heavy mortality and no longer cover the bottom of crevices, barnacle larvae and spat colonize this unoccupied space. Thus, the lower limit of barnacles is set, in part, by preemptive competition with mussels. This situation is analogous to that observed in the intertidal zone where the lower limit of barnacles is determined by lack of settlement due to space monopolization by a lower shore species (Denley \& Underwood 1979, Peterson 1979).

The most common interaction between barnacles and mussels described in the literature is interference competition (see Lewis 1976, Menge \& Sutherland 1976, Peterson 1979, Paine 1984). Within crevices, there were living and dead barnacles attached to the walls under the mussel mat, indicating smothering. To understand the relative importance of preemptive and interference competition, mussel dislodgment and recolonization in crevices should be examined.

At the beginning of this study, mussels were already established in crevices and slightly overlapped the barnacle zone. However, as sediments and faeces accumulated on the crevice bottom below mussels, those individuals overlying the soft substrata became unstable due to hummocking and decreased attachment. In autumn 1980, the mussels already appeared to be weakly attached and mussel cover had been considerably reduced by April 1981. Hummocking of Mytilus edulis on soft sediments outside of crevices has been abundantly documented elsewhere (Seed 1976, Grant 1977, Lubchenco \& Menge 1978, Wethey 1979). On relatively uniform surfaces replacement of holes in mussel beds can occur by an inward movement of perimeter mussels (Paines \& Levin 1981). However, this is not possible in crevices surrounded by bare surfaces. In crevices, colonization and build-up of a mussel mat is highly dependent on variations in larval recruitment and chance events associated with the entrapment of dislodged adults, presumably from the lower intertidal zone. The replacement of a mussel cover on the bottom of crevices takes at least 4 to 5 years (pers. obs.), depending on initial patch size. As a result, crevices in which mussels are removed simultaneously do not have synchronous recovery. Thus, in a location, one always find crevices in a variety of stages of recovery. This was not the case for crevices analysed in this study since only those with a well-developed mussel cover were initially selected. As a result of the advanced stage of these crevice communities, most (18 out of 21) lost their mussel cover during the first winter of observation.

The removal of mussels results in colonization by barnacles and their recruitment continues until invasion by mussels reduces space availability. Only bar- 
nacles that previously settled below the adult barnacle zone are smothered by mussels, some 2 to 5 yr after the disturbance process is initiated. Therefore, interference competition between mussels and barnacles in a given crevice is probably periodic varying with the rate of mussel recovery, barnacle settlement density and spatial position of settling larvae. Thus, the distribution of barnacle populations on crevice sidewalls results from both physical and competitive forces and a true spatial refuge is only achieved on a vertical range of about 5 to $20 \mathrm{~cm}$ above the crevice bottom.

Wave exposure is known to influence considerably the relation between Semibalanus balanoides and Mytilus edulis either by changing the relative abundance of the 2 species (Menge 1976, Grant 1977) or by influencing the activity of predators (Menge 1976, Lubchenco \& Menge 1978, Peterson 1979). When considering exposure, one usually refers to spatial scales of the order of at least the width of the intertidal zone. In this study we show that very small variations of crevice angle $\left(\simeq 30^{\circ}\right)$, which presumably induce variations in exposure, influence considerably the abundance and distribution of species as well as their interactions. Since in our study area $S$. balanoides occupies only a narrow vertical range both on the shore and within crevices, such fine variations of substratum hereogeneity are of prime importance in controlling community structure.

\section{Limits of seaweed}

In crevices Fucus vesiculosus holdfasts were limited to the barnacle zone. This distribution can best be explained by the following: (1) increased sporeling settlement and/or survival due to increased surface roughness and/or greater surface area provided here by barnacle shells (Burrows \& Lodge 1950, Lewis \& Bowman 1975, Choat 1977, Harling \& Lindberg 1977, Hawkins 1981, Lubchenco 1983), (2) seaweed settlement may be inhibited in the mussel zone (Hawkins \& Hartnoll 1983) or dislodged by mussels due to chafing of their stipe (Paine 1969, Grant 1977) or by smothering (Menge 1976). The latter processes were observed to occur in the crevices.

\section{The importance of spatial heterogeneity}

The relative importance of spatial heterogeneity varies for various communities. In tropical intertidal habitats, several studies have shown that substratum complexity can reduce the level of predation or mortality from physical stress (see Leviten \& Kohn 1980, Menge \& Lubchenco 1981, Garrity 1984) and the per- sistence of most species seems to be entirely dependent upon the availability of 3-dimensional spatial refuges (Menge \& Lubchenco 1981). In temperate communities, however, there are relatively fewer types of consumers. Predation and herbivore pressure appear to show strong seasonal variations and thus there are additional escapes (time, size) against predators (Menge \& Luchenco 1981). As a result, these authors concluded that substratum heterogeneity plays a less important role in temperate than in tropical communities. In contrast, our study of an intertidal community exposed to harsh winter conditions where consumers are absent and sessile species are few showed that the availability and type of spatial refuges provided by substratum irregularities are important factors determining species distribution, abundance, and persistence.

The effect of ice disturbance on subarctic sessile epifauna seems analogous to the effect of consumers on tropical sessile invertebrates. Moreover, the zonation of species we observed in crevices is similar to that observed in artificial holes placed in rocky zones of tropical intertidal areas (Menge et al. 1983). However, both the spatial scale studied and number of species differ. The artificial holes investigated by Menge et al. (1983) were cryptic habitats colonized by colonial animals and encrusting algae whereas our microhabitats were large depressions in the rock surface where, except for Littorina spp., only sessile solitary organisms are found. In the tropics, the species in experimental holes are determined by grazing pressure and their zonation is largely the result of a combination of their differing abilities to overgrow one another, physical stress and resistance to grazing. In subarctic crevices, biological interactions (preemption of space and presumably interference) operate but their intensity varies in space (due to crevice shape) and time (due to recovery rate of mussels and to barnacle settlement density)

Acknowledgements. We are especially grateful to C. Nolette and $\mathrm{G}$. Brochu of the Centre de Traitement de l'Information for programming assistance. G. Drouin, G. Vigneault and A. Gagné provided assistance in the field and $M$. Bousquet helped in the laboratory. We thank L. Gendron, Dr. John Himmelman and 3 anonymous reviewers for criticizing the manuscript. This research was supported by NSERC and FCAC grants to E. B. and by scholarships to the senior author from GIROQ and the Department of Education of Québec.

\section{LITERATURE CITED}

Archambault, D., Bourget, E. (1983). Importance du régime de dénudation sur la structure et la succession des communautés intertidales de substrats rocheux en milieu subarctique. Can. J. Fish. Aquat. Sci. 40: 1278-1292

Bergeron, P., Bourget, E. (1984). Effet du froid et des glaces 
sur les peuplements intertidaux des régions nordiques, particulièrement dans l'estuaire du Saint-Laurent. Océanis 10: 279-304

Bolton, J. J. (1983). Effect of short-term ice scouring on a Newfoundland rocky shore community. Astarte 12: 39-43

Bourget, E., Archambault, D., Bergeron, P. (1985). Effet des propriétés hivernales sur les peuplements epibenthiques intertidaux dans un milieu subarctique, l'estuaire du Saint-Laurent. Naturaliste can. 112: 131-142

Burrows, E. M., Lodge, S. M. (1950). Note on the interrelationship of Patella, Balanus, and Fucus on a semiexposed coast. Rep. mar. biol. Stn Port Erin 62: 30-34

Canadian Hydrographic Service (1984). Canadian tide and current tables, Vol. 3, St. Lawrence and Saguenay rivers. Fisheries and Oceans, Ottawa

Choat, J. H. (1977). The influence of sessile organisms on the population biology of three species of acmaeid limpets. $\mathrm{J}$. exp. mar Biol. Ecol. 26: 1-26

Connell, J. H. (1961). Effect of competition, predation by Thais lapillus and other factors on natural populations of the barnacle Balanus balanoides. Ecol. Monogr 31: 61-104

Conover, W. J. (1980). Practical non-parametric statistics. 2nd ed. Wiley, New York

Crisp, D. J. (1974). Factors influencing the settlement of marine invertebrate larvae. In: Grant, P. T., Mackie, A. M. (ed.) Chemoreception in marine organisms. Acadamic Press, London, p. 177-265

Dahl, A. L. (1973). Surface area in ecological analysis: quantification of benthic coral-reef algae. Mar. Biol. 23: 239-249

Denley, E. J., Underwood, A. J. (1979). Experiments on factors influencing settlement, survival, and growth of two species of barnacles in New South Wales. J. exp mar. Biol. Ecol. 36: 269-293

El-Sabh, M. I. (1979). The lower St. Lawrence Estuary as a physical oceanographic system. Naturaliste can. 106: $55-73$

Foster, B. A. (1971). On the determinants of the upper limit of intertidal distribution of barnacles (Crustacea: Cirripedia). J. Anim. Ecol. 40: 33-48

Garrity, S. D. (1984). Some adaptations of gastropods to physical stress on a tropical rocky shore. Ecology 65: 559-574

Grant, W. S. (1977). High intertidal community organization on a rocky headland in Maine, U.S.A. Mar. Biol. 44: 15-25

Hardwick-Witman, M. N. (1985). Biological consequences of ice rafting in a New England salt marsh community. J. exp. mar Biol. Ecol. 87: 283-298

Harlin, M. M., Lindberg, J. M. (1977). Selection of substrata by seaweeds: optimal surface relief. Mar Biol. 40: 33-40

Hawkins, S. J. (1981). The influence of season and barnacles on the algal colonization of Patella vulgata exclusion areas. J. mar biol. Ass. U.K. 51. 1-15

Hawkins, S. J., Hartnoll, R. G. (1983). Grazing of intertidal algae by marine invertebrates. Oceanogr mar. Biol. A Rev. 21: 195-282

Hooper, R. (1981). Recovery of Newfoundland benthic marine communities from sea ice. In: Fogg, G. E., Jones, W. E (ed.) Proc. Villth Int. Seaweed Symp., Bangor, North Wales. Marine Science Laboratories, Menai Bridge, Wales, p. 360-366

Leviten, P. J., Kohn, A. J. (1980). Microhabitat resource use, activity patterns, and episodic catastrophe: Conus on trop ical intertidal reef rock benches. Ecol. Monogr. 50: 55-75

Lewis, J. R. (1976). Long-term ecological surveillance: practical realities in the rocky littoral. Oceanogr. mar Biol. A Rev. 14: 371-390
Lewis, J. R., Bowman, R. S. (1975). Local habitat-induced variations in the population dynamics of Patella vulgata. J. exp. mar. Biol. Ecol. 17: 163-219

Lubchenco, J. (1983). Littorina and Fucus: effects of herbivores, substratum heterogeneity, and plant escapes during succession. Ecology 64: 1116-1123

Lubchenco, J., Menge, B. A. (1978). Community development and persistence in a low rocky intertidal zone. Ecol Monogr. 59: 67-94

Luckens, P. A. $\{1970\}$. Breeding, settlement and survival of barnacles at artificially modified shore levels at Leigh, New Zealand. N. Z. J1 mar. Freshwat. Res. 4: 497-514

Mathieson, A. C., Penniman, C. A., Busse, P. K., TreterGallagher, E. (1982). Effects of ice on Ascophyllum nodosum within the Great Bay estuary system of New Hampshire-Maine. J. Phycol. 18: 331-336

Menge, B. A. (1976). Organization of the New England rocky intertidal community: role of predation, competition, and environmental heterogeneity. Ecol. Monogr. 46: 355-393

Menge, B. A., Lubchenco, J. (1981). Community organization in temperate and tropical rocky intertidal habitats: prey refuges in relation to consumer pressure gradient. Ecol. Monogr. 51: 429-450

Menge, B. A., Sutherland, J. P. (1976). Species diversity gra. dients: synthesis of the roles of predation, competition, and temporal heterogeneity. Am. Nat. 110: 351-369

Menge, B. A., Ashkenas, L. R., Matson, A. (1983). Use of artificial holes in studying community development in cryptic marine habitats in a tropical rocky intertidal region. Mar. Biol. 77: 129-142

Morrisson, D. F. (1976). Multivariate statistical methods. McGraw-Hill, New York

Nie, N. H., Hull, C. H., Jenkins, J., Steinbrenner, K., Bent, D. H. (1975). Statistical package for the social sciences McGraw-Hill

O'Clair, C. E. (1981). Disturbance and diversity in a boreal marine community: the role of intertidal scouring by sea ice. In: Hood, D. W. Calder, J. A. (ed.) The eastern Bering Sea shelf: oceanography and resources, Vol. II. Univ. of Washington Press, Seattle, p. 1105-1130

Paine, R. T. (1969). The Pisaster-Tegula interaction: prey patches, predator food preference and intertidal community structure. Ecology 50: 950-961

Paine, R. T (1984). Ecological determinism in the competition for space. Ecology 65: 1339-1348

Paine, R. T., Levin, S. A. (1981). Intertidal landscapes: disturbance and the dynamics of pattern. Ecol. Monogr. 51: $145-178$

Peterson, C. H. (1979). The importance of predation and competition in organizing the intertidal epifaunal communities of Barnegat Inlet, New Jersey. Oecologia (Berl.) 39: $1-24$

Ricker, W. E. (1973). Linear regressions in fishery research. J. Fish. Res. Bd. Can. 30: 409-434

Rogers, C. S., Gilnack, M., Carl Fitz, III. H. (1983). Monitoring of coral reefs with linear transects: a study of storm damage. J. exp. mar Biol. Ecol. 66: 285-300

Seed, R. (1976). Ecology. In: Bayne, B. L. (ed.) Marine mussels: their ecology and physiology. Cambridge University Press, Cambridge, p. 13-65

Sokal, R. R., Rohlf, F. J. (1981). Biometry, 2nd ed. Freeman and Co. San Francisco

South, G. R. (1983). Benthic marine algae. In: South, G. R. (ed.) Biogeography and ecology of the Island of New. foundland. Dr. W Junk Publishers, The Hague

Underwood, A. J. (1981). Techniques of analysis of variance 
in experimental marine biology and ecology. Oceanogr. mar. Biol. A. Rev. 19: 513-605

Wellington, G. M. (1982). Depth zonation of corals in the Gulf of Panama: control and facilitation by resident fishes. Ecol. Monogr. 52: 223-241

Wethey, D. S. (1979). Demographic variation in intertidal barnacles. Ph. D. thesis, Univ, of Michigan
Wethey, D. S. (1983). Geographic limits and local zonation: the barnacles Semibalanus (Balanus) and Chthamalus in New England. Biol. Bull mar biol. lab., Woods Hole 165: 330-341

Winer, B. J. (1971). Statistical principles in experimental design. McGraw-Hill, Tokyo

This paper was presented by Dr. A. J. Southward; it was accepted for printing on September 25, 1985 